\title{
Karaciğer, safra kesesi ve safra yolu kanserlerinde epidemiyoloji ve sağ kalım özellikleri
}

\section{The epidemiological and survival features of liver, gallbladder, and biliary tract cancers}

\author{
İlker Turan ${ }^{1}$ \\ Fulya Günşar ${ }^{1}$ \\ Ömer Özütemiz ${ }^{1}$ \\ Ömer Vedat Ünalp ${ }^{2}$ \\ Fatih Tekin $^{1}$ \\ Galip Ersöz ${ }^{1}$ \\ Ahmet Çoker ${ }^{2}$ \\ Zeki Karasu $^{1}$ \\ Alper Uğuz ${ }^{2}$ \\ Erdem Göker ${ }^{3}$ \\ Murat Sözbilen² \\ Deniz Nart ${ }^{4}$ \\ Ayşe Caner ${ }^{5}$ \\ Ayfer Haydaroğlu ${ }^{6}$ \\ Funda Yılmaz ${ }^{4}$ \\ ${ }^{1}$ Ege Üniversitesi Tıp Fakültesi, Gastroenteroloji Bilim Dalı, İzmir, Türkiye \\ Ulus Salih Akarca ${ }^{1}$ \\ ${ }^{2}$ Ege Üniversitesi Tıp Fakültesi, Genel Cerrahi Anabilim Dalı, İzmir, Türkiye \\ ${ }^{3}$ Ege Üniversitesi Tıp Fakültesi, Medikal Onkoloji Bilim Dalı, İzmir, Türkiye \\ ${ }^{4}$ Ege Üniversitesi Tıp Fakültesi, Patoloji Anabilim Dalı, İzmir, Türkiye \\ ${ }^{5}$ Ege Üniversitesi Tıp Fakültesi, Kanserle Savaş Araştırma ve Uygulama Merkezi, İzmir, Türkiye \\ ${ }^{6}$ Ege Üniversitesi Tıp Fakültesi, Radyasyon Onkolojisi Anabilim Dalı, İzmir, Türkiye
}

Öz

Amaç: Ege Üniversitesi Hastanesinde 1992-2017 arası kanser tanı ve tedavisi yapılan 3791 karaciğer, safra kesesi ve safra yolu kanseri hastasının epidemiyolojik ve sağ kalım özelliklerinin karşılaştııılmasıdır.

Gereç ve Yöntem: Ege Üniversitesi Kanserle Savaş Araştırma ve Uygulama Merkezi tarafından toplanan hepatosellüler kanser, intrahepatik ve ekstrahepatik kolanjiosellüler karsinom, safra kesesi ve ampulla Vater tümörleri verileri DSÖ ve SEER sistemleri temelinde gruplanarak analizler yapılmıştır. Tümörlerin yaşam süreleri, farklı evrelerdeki sağ kalım ve yaşam süresi farkları, cinsiyet, yaş ve uygulanan tedavilerin sağ kalım ile ilişkileri araştırılmıştır.

Bulgular: 3791 hastadan 1832 hasta hepatosellüler kanser (HSK), 440 hasta intrahepatik kolanjiokarsinoma, 447 hasta ekstrahepatik kolanjiokarsinoma, 540 hasta safra kesesi kanseri ve 532 hasta ampulla Vater kanseri tanısı almıştı. HSK, kolanjiokarsinomlar ve ampulla Vater kanseri erkeklerde, safra kesesi kanseri ise kadın olgularda daha fazla idi. TNM sınıflanmasına göre tüm gruplarda hastaların daha çok ileri evrede olduğu görülmüştür ve en fazla ileri evre hasta olan grup safra kesesi kanserleriydi.

Ortalama sağ kalım süreleri HSK için 15 ay, intrahepatik kolanjiokarsinom için sekiz ay, ekstrahepatik kolanjiokarsinom için 10 ay, safra kesesi kanseri için sekiz ay ve ampulla Vater kanseri için 19 ay bulunmuştur. Tedavi modalitelerine göre bakıldığında tüm kanser gruplarında cerrahi tedavi uygulanan hastalarda yaşam süresi daha uzundu. Radyoterapi (RT) uygulamasının sadece safra kesesi kanseri olan hastalarda hayatta kalma üzerine olumlu etkisi bulunmuştur. Kemoterapi (KT) verilmesi intra/ekstrahepatik kolanjiokarsinom ve safra kesesi kanserlerinde hayatta kalmada uzama ile ilişkili bulunurken, HSK ve ampulla Vater kanseri olan hastalarda KT verilen ve verilmeyen hastalar arasında yaşam süresi açısından fark bulunmamıştır.

Sonuç: Bu seri 3791 hasta ile hepatobiliyer kanserlerle ilgili Türkiye'de yayınlanmış olan en geniş seridir. Hastalar genelde ileri evrede tanı almaktadır. Cerrahi tedavi tüm gruplarda, RT ve KT ise bazı gruplarda sağ kalım süresinde uzama ile ilişkilidir.

Anahtar Sözcükler: Hepatobiliyer kanser, epidemiyoloji, insidans, mortalite, genel sağ kalım.

\footnotetext{
Yazışma Adresi: Ayfer Haydaroğlu

Ege Üniversitesi Tıp Fakültesi, Radyasyon Onkolojisi

Anabilim Dalı İzmir, Türkiye

E-mail: haydaroglua@gmail.com
} 


\begin{abstract}
Aim: The aim of this study was to compare the epidemiological and survival features of 3791 liver, gallbladder, and biliary tract cancer patients who were diagnosed and treated between 1992 and 2017 at Ege University Hospital.
\end{abstract}

Materials and Methods: The database of Ege University Cancer Research for liver, gallbladder, and biliary tract cancers were grouped and analyzed based on DSO and SEER systems. Survival time for each tumor, survival times and survival differences for different stages of tumors, and the associations between survival times and the sex, age, and treatment modalities were investigated.

Results: Among 3791 cases, 1832 were hepatocellular carcinoma (HCC), 440 were intrahepatic cholangiocarcinoma, 447 were extrahepatic cholangiocarcinoma, 540 were gallbladder cancer, and 532 were ampullary cancer. HCC, cholangiocarcinomas, and ampullary cancer were more common in men; gallbladder cancers were more common in women. According to TNM classification, the patients were in advanced stages in all groups and the most advanced stage patients were in gallbladder cancer group. Median survival times were 15 months for HCC, 8 months for intrahepatic cholangiocarcinoma, 10 months for extrahepatic cholangiocarcinoma, 8 months for gallbladder cancer, and 19 months for ampullary cancer. When survival was evaluated according to treatment modalities, survival was longer in patients treated with surgery in all cancer groups. Radiotherapy (RT) had a positive effect on survival only in patients with gallbladder cancer. Whereas chemotherapy (CT) was associated with survival prolongation in intra/extrahepatic cholangiocarcinoma and gallbladder cancers, there was no survival difference favoring CT administration in patients with HCC and ampullary cancer.

Conclusion: This series is the largest of hepatobiliary cancers that was published in Turkey. Patients are usually diagnosed at an advanced stage. Surgical treatment is associated with prolongation of survival in all groups and RT and CT in some groups.

Keywords: Hepatobiliary cancer, epidemiology, incidence, mortality, overall survival.

\section{Giriş}

Karaciğer kanseri (hepatosellüler kanser-HSK) dünyada tanı konma sıklığı olarak erkeklerde 5beşinci sırada, kadınlarda ise dokuzuncu sırada yer alan en önemli kanser türlerinden biridir (1). HSK dünyada kanserden ölme sıklığında ise ikinci sırada yer alır (2). Amerika'da yıllık HSK insidansı 2010 yılında 100.000'de 6 olarak tespit edilmiştir (3). HSK insidansı coğrafik bölgelere göre geniş farklılıklar göstermektedir (4). Yine ırksal ve etnik farklılıklar söz konusudur. HSK dağılımının bu belirgin farklılığı muhtemelen hepatit virüsleri ve çevresel patojenlere maruziyetteki farklılıklara bağlıdır. Ülkemizde ne yazık ki insidans ile ilgili çalışma bulunmamaktadır. Tüm dünyada HSK'den yıllık ölüm oranları benzer şekilde rapor edilmiştir, bu da bu agresif hastalığın yüksek ölüm oranının önemine işaret etmektedir $(1,4)$. HSK insidans ve ölüm oranları dünyanın birçok bölgesinde (örneğin Kuzey Amerika, Latin Amerika, merkez Avrupa gibi) artış göstermektedir (1, 5, 6). Dünyanın tüm bölgelerinde erkeklerde HSK gelişimi kadınlardan daha fazladır. İnsidansın yüksek olduğu bölgelerde erkeklerde 2,1-5,7 kat daha fazla gözlenmektedir (4). Tam anlaşılamasa da cinsiyet dağılımdaki bu farklılık hepatit taşıyıcılığındaki farklıığa, çevresel toksinlere maruziyete, androjenlerin trofik etkisine ve/veya östrojenlerin koruyucu etkisine bağlı olarak düşünülmektedir (7).

Kolanjiokarsinoma terimi intrahepatik, perihiler veya ekstrahepatik (distal) safra yollarından köken alan kanserleri ifade eder, ampulla Vater ve safra kesesi tümörleri bundan hariçtir. Kolanjiokarsinomalar tüm gastrointestinal malignitelerin yaklaşık \%3'ünü oluşturur. Bir otopsi serisinde prevelans $\% 0,01-0,46$ olarak bildirilmiştir (8). Safra yolu kanserleri yaşla birlikte artar ve genelde 50-70 yaş arasında görülür. Nedeni tam bilinmemekle beraber intrahepatik kolanjiokarsinoma insidansı geçen iki dekatta Avrupa, Kuzey Amerika, Asya, Japonya ve Avustralya'da artış gösterirken, Dünya genelinde ekstrahepatik kolanjiokarsinom oranları azalmıştır $(9,10)$. Safra kesesi kanserlerine zit olarak, kolanjiokarsinom görülme oranı erkeklerde kadınlara göre biraz daha fazladır; bu muhtemelen primer sklerozan kolanjitin (PSK) erkeklerde daha fazla görülmesine bağlıdır. 
Safra kesesi kanserleri nadir kanser türlerindendir ancak oldukça fatal bir kanserdir. Dünyada görülme oranları coğrafik bölgelere göre oldukça farklılık göstermektedir ve bu kolelitiazis prevelansı ile koreledir. İnsidans yaş ile birlikte artar, kadınlarda erkeklere göre 2-6 kat daha fazla görülür ve beyaz ırkta siyahlara göre daha sıktır (11).

$\mathrm{Bu}$ makalede Ege Üniversitesi Hastanesi (EÜH)'nde, 1992-2017 arası kanser tanı ve tedavisi yapılan 3791 karaciğer, safra kesesi ve safra yolu kanseri hastasının epidemiyolojik ve genel sağ kalım özellikleri araştırılmış, sonuçlar kaynaklarla karşılaştırılmıştır.

\section{Gereç ve Yöntem}

EÜ Kanser Araştırma Merkezi (EÜKAM) tarafından 1992-2017 arası EÜH'de toplanan karaciğer, safra kesesi ve safra yolları kanseri verileri CANREG özel bilgisayar programına kaydedilmiştir. Bu veriler DSÖ ve SEER sistemleri temelinde gruplanarak analizler yapılmıştır.

İstatistik analizlerde Ki-kare, General Linear Model (GLM), Kaplan Meier sağ kalım analizleri uygulanmıştır. Kaplan Meier Sağ kalım analizinde Log Rank (Mantel-Cox), Breslow (Generalized Wilcoxon) ve Tarone-Ware istatistikleri kullanılmıştır. İstatistik analizlerde $p<0,05$ istatistiksel olarak anlamlı kabul edilmiştir.

\section{Bulgular}

EÜH Kanser veri sisteminde bulunan 117.139 olgudan 1832 hasta HSK $(\% 1,6), 440$ hasta intrahepatik kolanjiokarsinoma $(\% 0,4), 447$ hasta ekstrahepatik kolanjiokarsinoma $(\% 0,4), 540$ hasta safra kesesi kanseri $(\% 0,5)$ ve 532 hasta ampulla Vater $(\% 0,5)$ kanseri tanısı almıştı (toplam 3791 hasta). Literatürle uyumlu olarak HSK, safra yolu kanserleri ve ampulla Vater kanseri erkeklerde, safra kesesi kanseri ise kadın olgularda daha fazla idi (Tablo-1). HSK olgularının \%76'sını erkek hastalar oluşturmaktaydı. HSK hastaları safra kesesi ve kolanjiokarsinoma hastalarına göre daha genç olup ortalama yaş $( \pm S D) \quad 58.9 \pm 15.3$ idi $(p<0,0001)$. İntrahepatik kolanjiokarsinoma hastaları ekstrahepatik olanlara göre biraz daha genç idi $(62.1 \pm 13.5$ / 64.8 $\pm 12.7, p<0.0001)$.

Tümör, nod ve metastaz (TNM) sınıflanmasına göre kanserler incelendiğinde tüm gruplarda hastaların daha çok ileri evrede olduğu görülmüştür (Şekil-1). En fazla ileri evre hasta olan grup safra kesesi kanserleriydi, daha sonra kolanjiokarsinom gelmekteydi. Ancak tüm gruplarda önemli oranda hastada TNM evresini belirleyecek verilerin yetersiz olduğu görülmüştür (Şekil-1).

Tüm grupta genel yaşam süresi ortalama 12 ay (\%95 Cl: 11-13) idi (Şekil-2). Tümör tiplerine göre yaşam süreleri incelendiğinde HSK için ortalama 15 ay (\%95 Cl: 13-17), intrahepatik kolanjiokarsinom için ortalama 8 ay (\%95 Cl: 69), ekstrahepatik kolanjiokarsinom için ortalama 10 ay (\%95 Cl: 7-12), safra kesesi kanseri için ortalama 8 ay (\%95 Cl: 7-10) ve ampulla Vater kanseri için ortalama 19 ay (\%95 Cl: 14-22) bulunmuştur (Şekil-3).

Cinsiyete göre yaşam sürelerine bakıldığında HSK grubunda kadın hastalarda yaşam süresinin daha uzun olduğu görülmüştür (ortalama 22 ay vs 13 ay, $p=0.0009$ ) (Şekil-4). Diğer kanserlerde cinsiyete göre yaşam sürelerinde fark bulunmamıştır.

Tüm grupta TNM evrelerine göre yaşam sürelerine bakıldığında beklendiği üzere tümör evresi ileri, lenf nodu ve uzak metastazı olanlarda yaşam süresi belirgin olarak daha düşük saptanmıştır (Şekil-5 A, B, C). Tümör evresi ileri olanlarda ortalama yaşam süresi 10 ay $\% 95 \mathrm{Cl}$ : 8-12) iken, lokal evrede olan hastalarda yaşam süresi ortalama 21 ay $(\% 95 \mathrm{Cl}$ : 18-23) olarak belirlenmiştir $(p<0,0001)$.

Uygulanan tedavi modalitelerine göre yaşam süresine bakıldığında tüm kanser gruplarında cerrahi tedavi uygulanan hastalarda yaşam süresi uygulanmayanlara göre daha uzundu (Şekil-6 A-E).

Radyoterapi (RT) uygulamasının sadece safra kesesi kanseri olan hastalarda hayatta kalma üzerine olumlu etkisi vardı (uygulananlarda ortalama süre 16 ay, uygulanmayanlarda ortalama süre 8 ay, $p=0,0092$ ) (Şekil-7). Diğer gruplarda RT uygulanan ve uygulanmayan hastalar arasında yaşam süresi açısından fark bulunmamıştır.

Kemoterapi (KT) verilmesi ise intra/ekstrahepatik kolanjiokarsinom ve safra kesesi kanserlerinde yaşam süresinde uzama ile ilişkili bulunurken (Şekil-8 A, B, C), HSK ve ampulla Vater kanseri olan hastalarda KT verilen ve verilmeyen hastalar arasında yaşam süresi açısından fark bulunmamıştır. 
Tablo-1. Tümör tiplerine göre yaş ve cinsiyet oranları.

\begin{tabular}{lccc}
\hline Tümör & N & $\begin{array}{c}\text { Yaş } \\
\text { (ortalama } \pm \text { standart sapma) }\end{array}$ & $\begin{array}{c}\text { Cinsiyet } \\
(\% \mathrm{E})\end{array}$ \\
\hline Hepatosellüler Kanser & 1832 & $58,9 \pm 15,3^{\mathrm{a}}$ & 75,9 \\
Intrahepatik Kolanjiokarsinoma & 440 & $62,1 \pm 13,5^{\mathrm{b}}$ & 53,6 \\
Safra Kesesi Kanseri & 540 & $64,4 \pm 11,5^{\mathrm{c}}$ & 36,9 \\
Ekstrahepatik Kolanjiokarsinoma & 447 & $64,8 \pm 12,7^{\mathrm{d}}$ & 54,4 \\
Ampulla Vater Kanseri & 532 & $64,2 \pm 12,1^{\mathrm{e}}$ & 63,5 \\
Total & 3791 & $61,5 \pm 14,1$ & 63,5
\end{tabular}

p değerleri: a-b:<0,0001; a-c:<0,0001; a-d:<0,0001; a-e:<0,0001; b-c:0,086; b-d: 0,032; b-e: 0,161; c-d: 1,000; c-e: 1,000; d-e: 1,000

Cinsiyet farkı $p<0,0001$

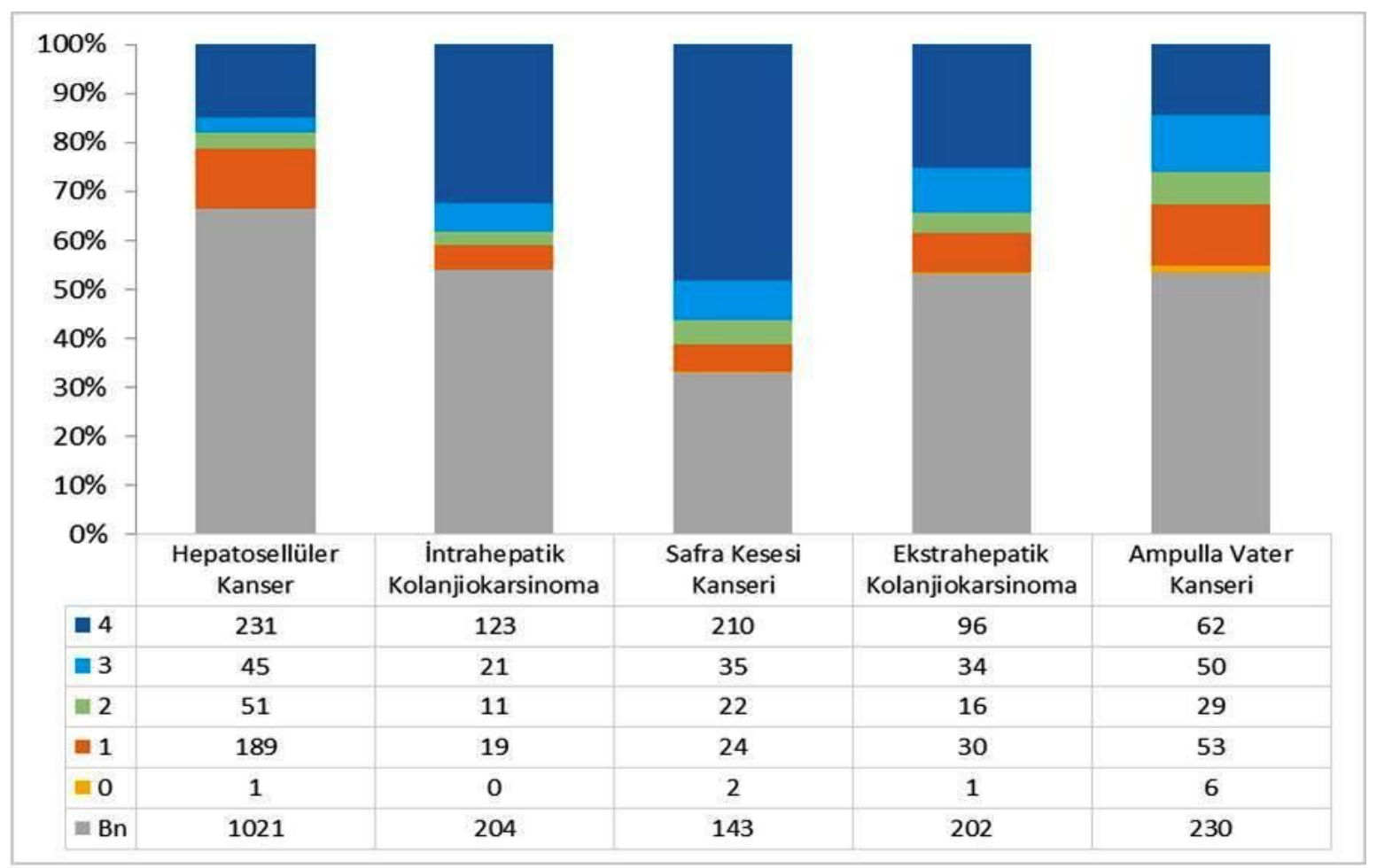

$\mathrm{p}<0,0001, \mathrm{Bn}$ : bilinmeyen

Şekil-1. Tümör tipi ve TNM evreleri. 


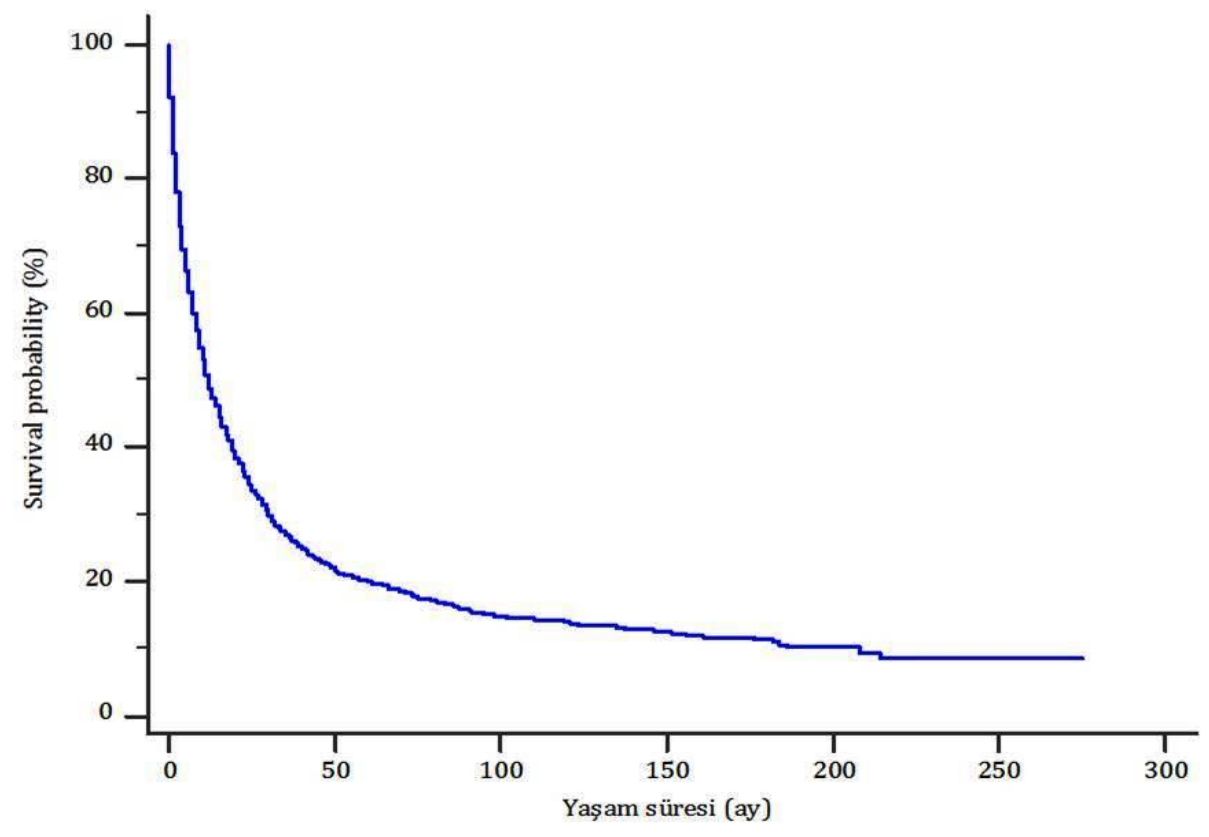

\begin{tabular}{|r|r|r|r|r|}
\hline Mean & SE & $95 \%$ Cl for the mean & Median & $95 \%$ Cl for the median \\
\hline 47.666 & 1.932 & 43.880 to 51.451 & 12.000 & 11.000 to 13.000 \\
\hline
\end{tabular}

Şekil-2. Genel yaşam süresi.

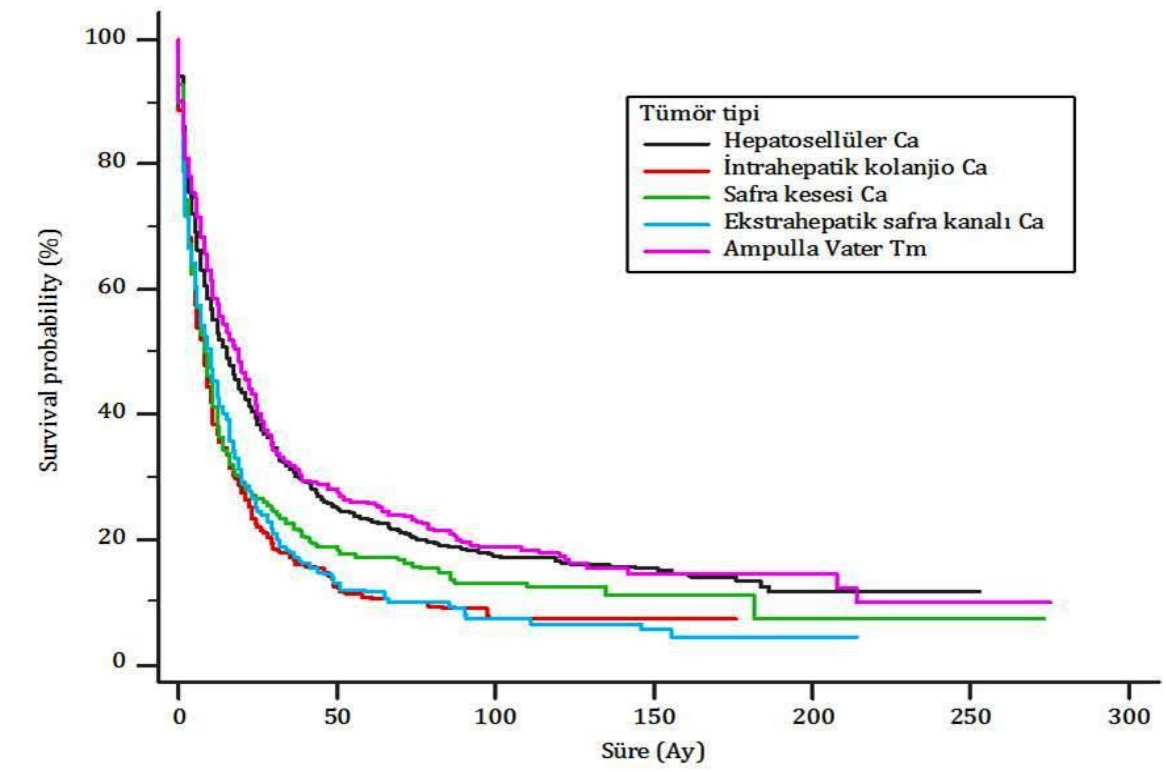

\begin{tabular}{|l|r|r|r|r|r|}
\hline Factor & Mean & SE & $95 \%$ Cl for the mean & Median & $95 \%$ Cl for the median \\
\hline $\begin{array}{l}\text { Hepatosellüler } \\
\text { Kanser }\end{array}$ & 53.170 & 2.599 & 48.075 to 58.264 & 15.000 & 13.000 to 17.000 \\
$\begin{array}{l}\text { Intrahepatik } \\
\text { kolanjiokarsinom }\end{array}$ & 25.437 & 2.674 & 20.195 to 30.679 & 8.000 & 6.000 to 9.000 \\
\hline $\begin{array}{l}\text { Safra kesesi kanseri } \\
\text { Ekstrahepatik }\end{array}$ & 40.649 & 5.171 & 30.513 to 50.785 & 8.000 & 7.000 to 10.000 \\
\hline kolanjiokarsinom & 27.140 & 3.098 & 21.067 to 33.213 & 10.000 & 7.000 to 12.000 \\
\hline $\begin{array}{l}\text { Ampulla Vater } \\
\text { Kanseri }\end{array}$ & 57.810 & 5.121 & 47.772 to 67.848 & 19.000 & 14.000 to 22.000 \\
\hline \begin{tabular}{l} 
Overall \\
\hline
\end{tabular} & 47.666 & 1.932 & 43.880 to 51.451 & 12.000 & 11.000 to 13.000 \\
\hline
\end{tabular}

Şekil-3. Tümör tiplerine göre yaşam süreleri. 


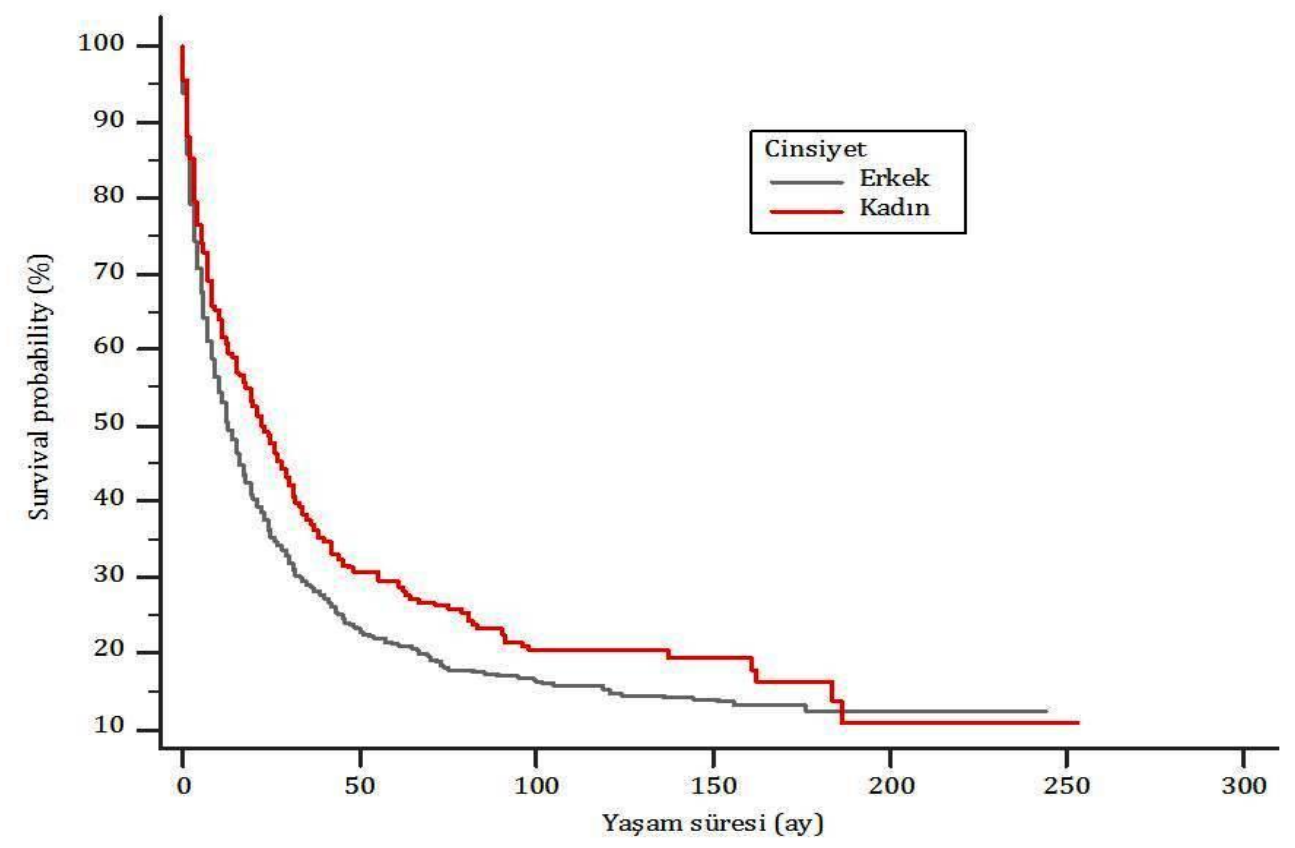

\begin{tabular}{|l|r|r|r|r|r|}
\hline Factor & Mean & SE & $95 \%$ Cl for the mean & Median & $95 \%$ Cl for the median \\
\hline Erkek & 49.634 & 2.783 & 44.180 to 55.088 & 13.000 & 12.000 to 15.000 \\
\hline Kadın & 61.604 & 5.451 & 50.921 to 72.287 & 22.000 & 18.000 to 28.000 \\
\hline Overall & 53.170 & 2.599 & 48.075 to 58.264 & 15.000 & 13.000 to 17.000 \\
\hline
\end{tabular}

\section{$P=0.0009$}

Şekil-4. Hepatosellüler kanser hastalarında cinsiyete göre yaşam süreleri.

A

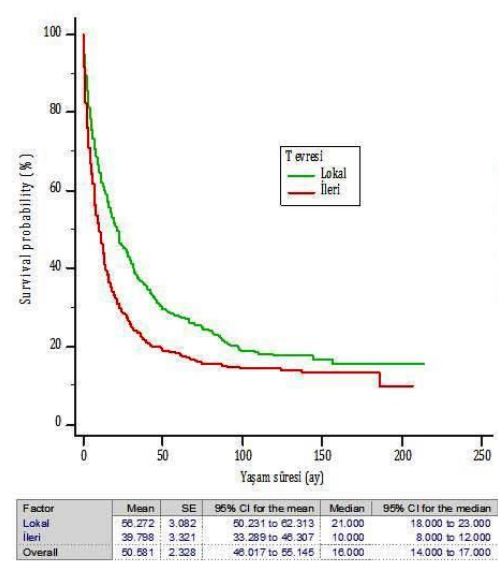

$\mathrm{P}<0.0001$
B
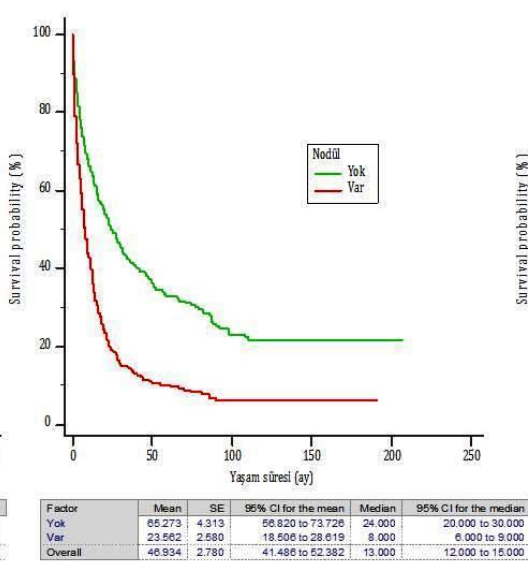

$\mathrm{P}<0.0001$
C
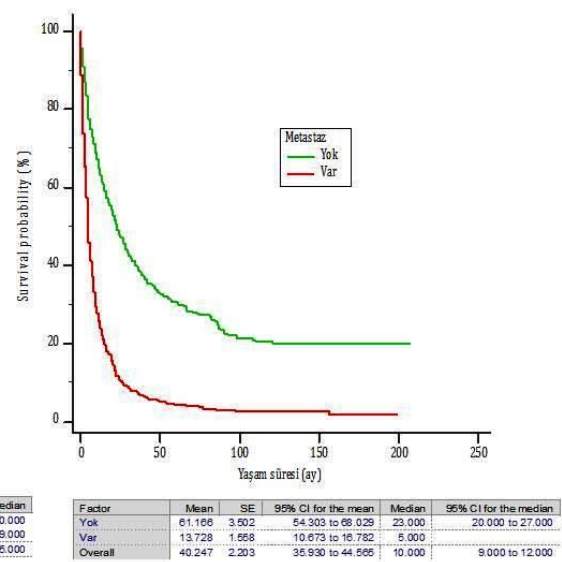

$\mathrm{P}<0.0001$

Şekil-5. Tüm grupta T evresine $(A)$, nodül $(B)$ ve metastaz $(C)$ durumuna göre yaşam süreleri. 

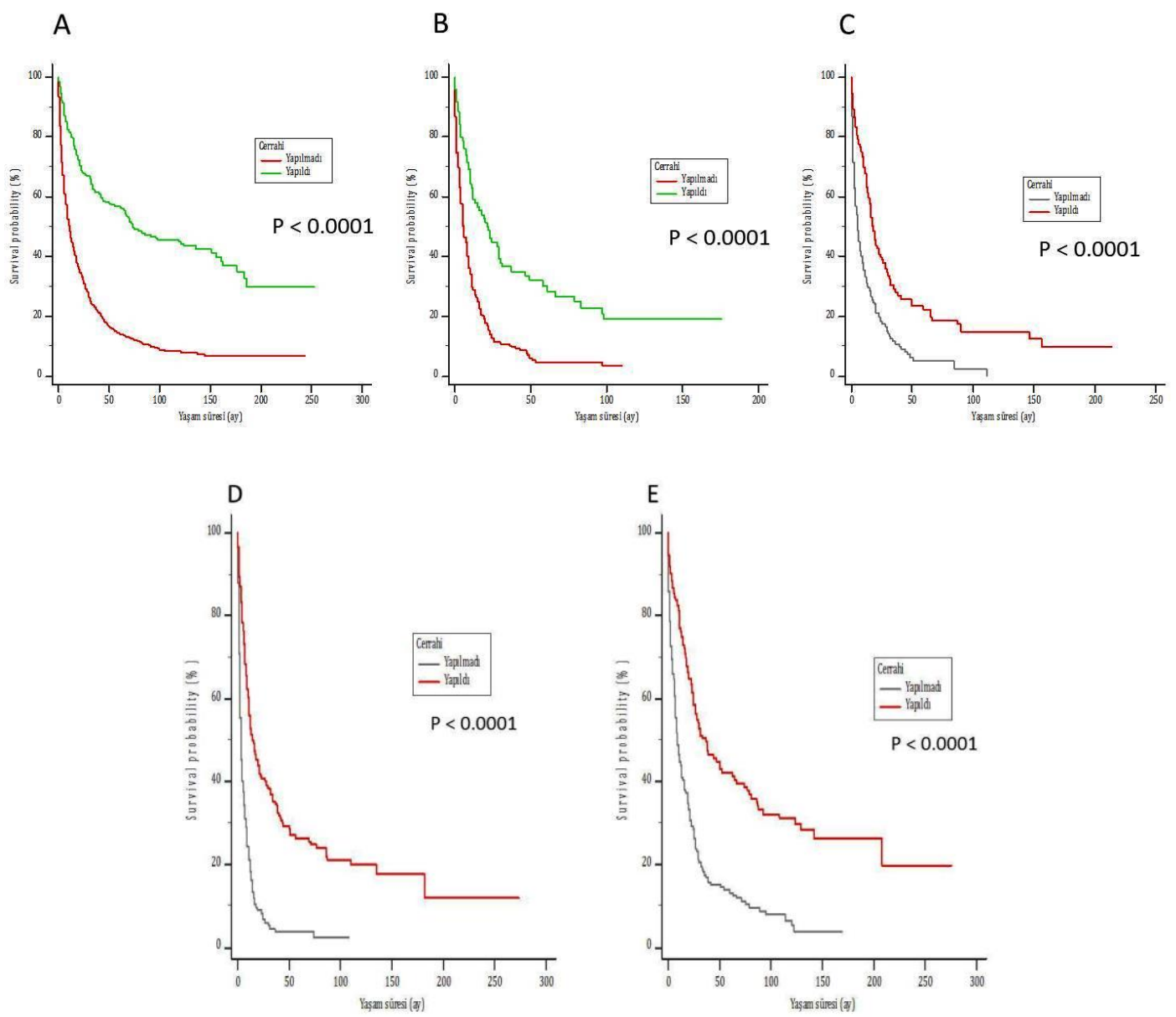

Şekil-6. Hepatosellüler kanser (A), intrahepatik (B) ve ekstrahepatik (C) kolanjiokarsinom, Safra kesesi kanseri (D) ve ampulla Vater kanseri (E) hastalarında cerrahi uygulanan ve uygulanmayan hastaların yaşam süresi.

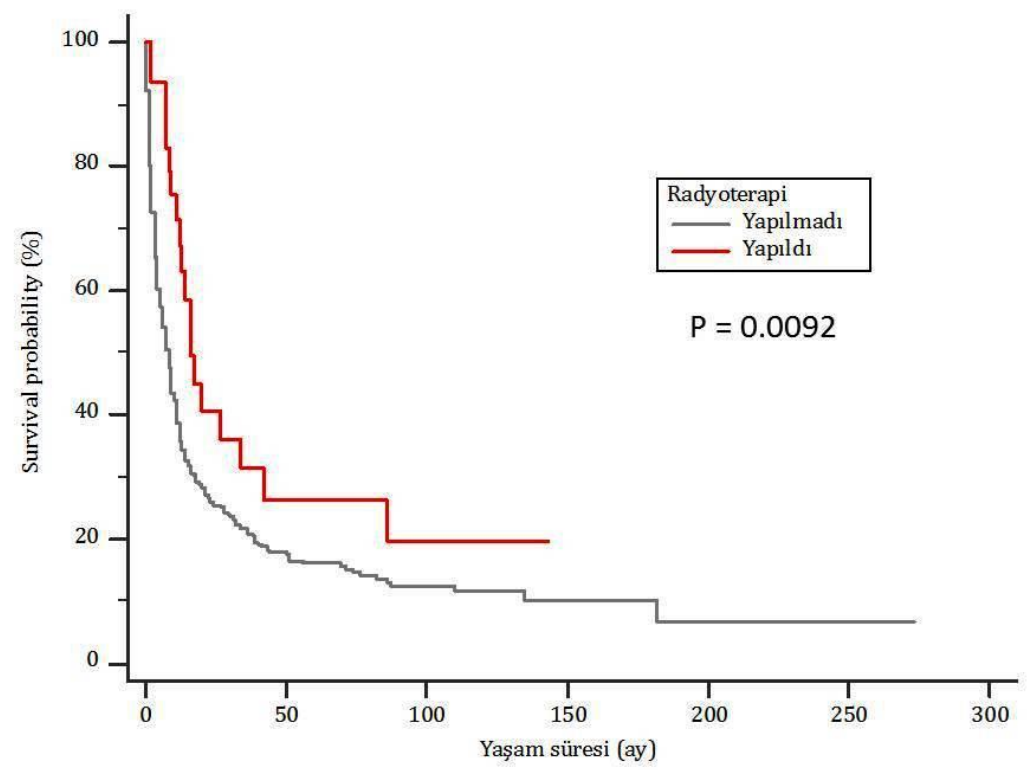

Şekil-7. Safra kesesi kanseri hastalarında radyoterapi uygulanan ve uygulanmayan hastaların yaşam süresi. 

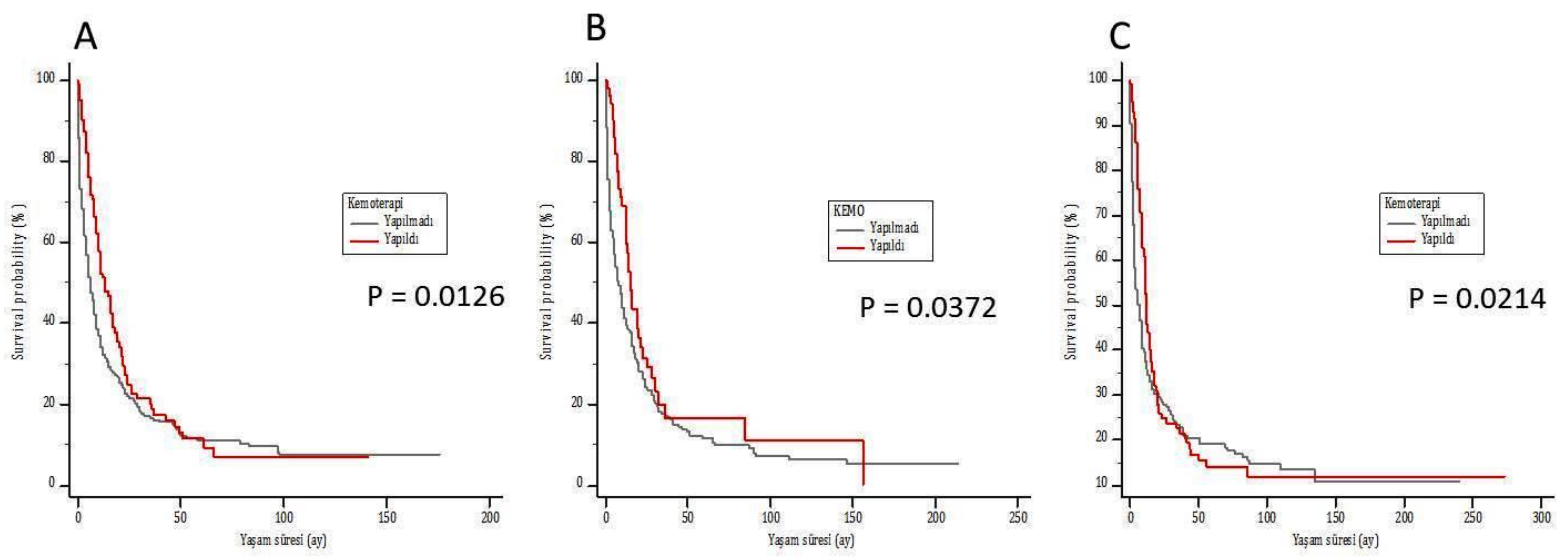

Şekil-8. Intrahepatik (A), ekstrahepatik (B) kolanjiokarsinom ve safra kesesi kanseri (C) hastalarında kemoterapi uygulanan ve uygulanmayan hastaların yaşam süresi.

Yıllara göre yaşam süresinde değişiklik olup olmadığını araştırmak için hastalar tanı tarihleri 2010 yilından önce ve sonra olmak üzere ikiye ayrıldı. Tüm grupta, ayrıca HSK, ekstrahepatik kolanjiokarsinoma ve ampulla Vater kanserlerinde 2010 yılından sonra tanı alanlarda yaşam süresi daha kısa bulundu. Örneğin HSK hastalarında 2010 yılından önce tanı alanlarda ortalama yaşam süresi 19 ay (\%95 Cl: 16-22) iken, 2010 yılından sonra tanı alanlarda ortalama 12 ay $(\% 95 \mathrm{Cl}: 11$ 15) bulunmuştur $(p=0,002)$. Yakın yıllarda yaşam süresinin kısalmış olması daha ileri evre hastalara müdahale ediliyor olmasına bağlı olabilir.

\section{Tartışma}

Primer karaciğer kanseri 2018 yılında tüm dünyada en sık görülen yedinci kanser ve kansere bağlı mortaliteninde en sık ikinci nedeni olarak saptanmıştır (2). HSK, birçok ülkede karaciğer kanserinin dominant histolojik tipidir ve vakaların yaklaşık \%75'ini oluşturur (12). HSK genellikle kronik hepatit $B$ veya $C$ virüs enfeksiyonu, aflatoksin maruziyeti, aşırı alkol tüketimi, obezite, diyabet ve sigara içme tarafından tetiklenen inflamasyon ve oksidatif stres temelinde ve genelde siroz zemininde gelişir. Tüm dünyada HSK görülme sıklığı erkeklerde kadınlara göre belirgin olarak daha fazladır ve bu bazı bölgelerde beş kata kadar çıkmaktadır (4). Bizim çalışmamızda da literatürle uyumlu olarak HSK vakalarının erkeklerde (\%76) anlamlı olarak daha fazla gözlenmiştir. Bu farklılığın HSK için risk faktörlerinin (HBV, HCV, alkol ve sigara) erkeklerde daha fazla olmasına veya cinsiyet steroid hormonları, immün cevaplar ve/veya kadınlar ve erkekler arasındaki epigenetik farklılıklara bağlı olduğu düşünülmektedir (13). Asya ve Avrupa'dan yapılan çeşitli büyük prospektif çalışmalarda tanı yaşı ortalama $50-60$ arasında bildirilmiştir (14-16). Bizim çalışmamızda da ortalama tanı yaşı 59 olarak bulunmuştur. HSK hastalarımızda tümör evresi lokal olan hasta oranı diğer gruplara (kolanjiokarsinomlar ve safra kesesi kanseri) göre daha fazlaydı (Şekil-1). Bunun muhtemelen siroz tanısı konan hastaların HSK açısından takibe alınmasına (genelde 6 ayda bir ultrason ve alfa-feto protein (AFP) ile takip) bağlı olduğu düşünülmüştür. Böylelikle hastalar daha erken evrede tanı alabilmektedir.

Yakın zamanda yayınlanan raporlarda HSK insidansında ve mortalitesinde dünyanın birçok bölgesinde artış, bazı Asya ülkelerinde de azalma bildirilmiştir (1, 17, 18). Tedavideki ilerlemelere rağmen birçok hasta tanı anında tedavi edilebilir değildir ve 5 yıllık yaşam süresi yaklaşık \%18'dir (19). Asya'dan yapılan bir çalışmada bir yıllık yaşam ortalama 10 ay saptanmıştır (20). Bizim çalışmamızda ortalama yaşam süresi 15 ay bulunmuştur. Kadınlarda erkeklere göre ve cerrahi uygulanan hastalarda uygulanmayanlara göre yaşam süresi daha fazlaydı. Yaşam süresi üzerine etkili olan faktörler (siroz etiyolojisi, survelans programında tanı konulması, karaciğer transplantasyonu gibi) EÜKAM verilerinde olmadığı için analiz edilememiştir.

Intrahepatik ve ekstrahepatik kolanjiokarsinomlar tüm hepatobiliyer malignitelerin yaklaşık \%1020 'sini oluşturur ve en sık ikinci primer karaciğer tümörüdür. Tanı konulduğunda genelde ileri evrededir. Son dekatlarda intrahepatik 
kolanjiokarsinom insidansında dünyada artış gözlenmektedir. Amerika'da her yıl 5000 yeni kolanjiokarsinom vakası bildirilmektedir (21). Ortalama tanı yaşı intrahepatik kolanjiokarsinomlarda 50'li yaşların ortası iken bu 60'lı yaşların ortasına doğru değişim göstermiştir. Bu gözlem yaşlı popülasyonda kronik karaciğer hastalıklarında artışa veya tanı, takip ve risk faktörlerinin yönetimindeki (örneğin PSK) iyileşmelere bağlı olabilir. Bizim çalışmamızda da ortalama tanı yaşı 62 olarak bulunmuştur ve literatürle uyumludur. Ektrahepatik kolanjiokarsinom hastalarımızın tanı yaşı ise biraz daha ileri idi (ortalama 64), ancak fark istatistiksel olarak anlamlıydı. Kolanjiokarsinomlar safra kesesi tümörlerinden farklı olarak erkeklerde biraz daha fazla gözlenmektedir. Bu çalışmada da literatürle uyumlu olarak hem intrahepatik hem de ekstrahepatik kolanjiokarsinomlar erkeklerde biraz daha fazla tespit edilmiştir (sırasıyla \%53 ve \%54). Kolanjiokarsinom vakalarımız literatürle uyumu olarak tanı anında ileri evrede idi ve ortalama yaşam süresi intrahepatik kolanjiokarsinom vakalarında sekiz ay, ekstrahepatik olanlarda 10 ay olarak tespit edildi. Literatürle uyumlu olarak cerrahi ve KT uygulanan hastalarda yaşam süreleri daha iyi bulunmuştur. RT'nin ise yaşam süresi üzerine bir etkisi saptanmamıştır. Negatif cerrahi kenarlı (R0) rezeksiyon, kolanjiokarsinomların tüm alt tipleri için potansiyel olarak küratif tedavidir, ancak bu hastaların ancak $1 / 3$ 'ünde başarılabilir. Maalesef bu hastaların da yarısından fazlası tanı anında ileri evrededir. En iyi sonuçlar (beş yıllık rekürrenssiz sağ kalım \%68) seçilmiş perihiler kolanjiokarsinom hastalarında neoadjuvan kemoterapi ve takiben ortotopik karaciğer transplantasyonu ile sağlanmıştır (22).

Safra kesesi kanserleri mortalitesi oldukça yüksek kanser türlerindedir. Vakaların çoğu ileri evrede tanı almaktadır, bunun muhtemelen nedeni hem safra kesesinin anatomik pozisyonu hem de semptomların nonspesifik olması olarak düşünülmektedir. Kadınlarda çok daha sık olarak izlenmektedir (2-6 kat) (11). Bizim çalışmamızda vakaların \%63'ünü kadınlar oluşturmaktaydı ve tanı yaşı ortalama 64 idi. Bu bulgular literatürle uyumluydu. Safra kesesi kanserlerinin tedavisinde sadece cerrahi potansiyel olarak küratif tedavidir. Ancak bu kanserde de az sayıda hastanın bu tedavi şansı olabilmektedir. Rezeksiyon şansı olmayan ileri evre hastalarda ortalama yaşam süresi genelde altı aydan kısadır. Nitekim bizim çalışmamızda da cerrahi uygulanmamış olan hastalarda ortalama yaşam süresi üç ay olarak tespit edilmiştir (Şekil-11). Yine literatürle uyumlu olarak RT ve KT alan hastalarda, almayanlara göre yaşam süresi daha uzun saptanmıştır.

Ampulla Vater kanserleri distal koledok ile pankreatik kanal bifürkasyonunda ampuller kompleks içinde gelişen tümörleri tanımlar. Genelde 60-70 yaşında tanı alırlar, bizim çalışmamızda da ortalama tanı yaşı 63 olarak saptanmıştır. Ampuller kanserlerde prognoz histolojik alt tip ve immünohistokimyasal paterne göre (histomoleküler pankreatikobiliyer fenotip ve intestinal fenotip) ile yakından ilişkilidir. Ayrıca lenf nodu metastazı olması prognozu önemli oranda etkilemektedir (23). Bizim çalışmamızda da lenf nodu metastazı yaşam süresi üzerinde anlamlı etkili bulunmuştur. Ancak fenotip paternleri bilinmediği için bu yönden analiz yapılamamıştır. Ayrıca literatürle uyumlu olarak cerrahi tedavi uygulanmasının yaşam süresinin uzaması anlamında oldukça faydalı olduğu izlenirken, RT ve KT'nin yaşam süresi üzerine etkisi gözlenmemiştir.

\section{Sonuç}

HSK erkek hastalarda belirgin olarak daha fazladır ve ortalama yaşam süresi 15 ay saptanmıştır. Cerrahi tedavi uygulananlarda yaşam süresi belirgin olarak daha uzundur. Kolanjiokarsinom vakalarından intrahepatik olanların yaşam süresi daha kısadır. Cerrahi, RT ve KT uygulanması bu hastalarda yaşam süresi üzerine olumlu etkilidir. Safra kesesi kanserleri hala mortalitesi oldukça yüksek kanserlerdir. Cerrahi tedavi uygulanamayan hastalarda ortalama yaşam süresi üç aydır. Cerrahi uygulanan hastalarda bu süre 14 aya çıkmaktadır. Ampulla Vater tümörlerinde cerrahi uygulanması yaşam süresi üzerine oldukça etkili bulunmuştur. RT ve KT'nin bu grupta yaşam süresi üzerine etkisi saptanmamıştır. Ayrıca tüm grupta yakın zamanda (2010'dan sonra) tanı konan hastalarda yaşam süresi daha kısa olduğu gözlenmiştir. Bu muhtemel daha ileri evre hastalara da artık tedavi modalitelerinin uygulanması ile ilişkili olduğu düşünülmüştür.

\section{Açıklamalar}

Bu çalışmanın yapılmasında yazarlar arasında herhangi bir çıkar çatışması bulunmamaktadır.

Katkıda bulunanlar: $\mathrm{Bu}$ çalışmada kullanılan verilerde, derginin bu sayısının önsözünde "Teşekkür Listesinde" belirtilen tüm Ege Üniversitesi Tıp Fakültesi Gastroenteroloji Bilim Dalı, Patoloji Anabilim Dalı, Genel Cerrahi Anabilim Dalı, Medikal Onkoloji Bilim Dalı ve Radyasyon Onkolojisi Anabilim Dalı öğretim üyelerinin katkıları olmuştur. 


\section{Kaynaklar}

1. Global Burden of Disease Liver Cancer Collaboration, Akinyemiju T, Abera S, Ahmed M, et al. The Burden of Primary Liver Cancer and Underlying Etiologies From 1990 to 2015 at the Global, Regional, and National Level: Results From the Global Burden of Disease Study 2015. JAMA Oncol. 2017; 3: 1683-91.

2. Bray F, Ferlay J, Soerjomataram I, Siegel RL, Torre LA, Jemal A. Global cancer statistics 2018: GLOBOCAN estimates of incidence and mortality worldwide for 36 cancers in 185 countries. CA Cancer J Clin 2018; 68: 394-424.

3. El-Serag HB, Kanwal F. Epidemiology of hepatocellular carcinoma in the United States: where are we? Where do we go? Hepatology. 2014; 60: 1767-75.

4. Jemal A, Bray F, Center MM, Ferlay J, Ward E, Forman D. Global cancer statistics. CA Cancer J Clin. 2011; 61: 69-90.

5. Ryerson AB, Eheman CR, Altekruse SF, et al. Annual Report to the Nation on the Status of Cancer, 19752012, featuring the increasing incidence of liver cancer. Cancer. 2016; 122: 1312-37.

6. Bosetti C, Levi F, Boffetta P, Lucchini F, Negri E, La Vecchia C. Trends in mortality from hepatocellular carcinoma in Europe, 1980-2004. Hepatology. 2008; 48: 137-45.

7. Naugler WE, Sakurai T, Kim S, Maeda S, Kim K, Elsharkawy AM, Karin M. Gender disparity in liver cancer due to sex differences in MyD88-dependent IL-6 production. Science. 2007; 317: 121-4.

8. Vauthey JN, Blumgart LH. Recent advances in the management of cholangiocarcinomas. Semin Liver Dis. 1994; $14: 109-14$.

9. Khan SA, Emadossadaty S, Ladep NG, Thomas HC, Elliott P, Taylor-Robinson SD, Toledano MB. Rising trends in cholangiocarcinoma: is the ICD classification system misleading us? J Hepatol. 2012; 56: 848-54.

10. Jepsen P, Vilstrup H, Tarone RE, Friis S, Sørensen HT. Incidence rates of intra- and extrahepatic cholangiocarcinomas in Denmark from 1978 through 2002. J Natl Cancer Inst. 2007; 99: 895-7.

11. Randi G, Franceschi S, La Vecchia C. Gallbladder cancer worldwide: geographical distribution and risk factors. Int J Cancer. 2006; 118: 1591-602.

12. Altekruse SF, Devesa SS, Dickie LA, McGlynn KA, Kleiner DE. Histological classification of liver and intrahepatic bile duct cancers in SEER registries. J Registry Manag 2011; 38: 201-5.

13. Dorak MT, Karpuzoglu E. Gender differences in cancer susceptibility: an inadequately addressed issue. Front Genet 2012; 3: 268.

14. Beasley RP, Hwang LY, Lin CC, Chien CS. Hepatocellular carcinoma and hepatitis B virus. A prospective study of 22707 men in Taiwan. Lancet. 1981; 2: 1129-33.

15. Colombo M, de Franchis R, Del Ninno E, et al. Hepatocellular carcinoma in Italian patients with cirrhosis. N Engl J Med. 1991; 325: 675-80.

16. Tsukuma H, Hiyama T, Tanaka S, et al. Risk factors for hepatocellular carcinoma among patients with chronic liver disease. N Engl J Med. 1993; 328: 1797-801.

17. Bertuccio P, Turati F, Carioli G, et al. Global trends and predictions in hepatocellular carcinoma mortality. $J$ Hepatol 2017; 67: 302-9.

18. Liu Z, Jiang $\mathrm{Y}$, Yuan $\mathrm{H}$, et al. The trends in incidence of primary liver cancer caused by specific etiologies: Results from the Global Burden of Disease Study 2016 and implications for liver cancer prevention. J Hepatol 2019; 70: 674-83.

19. Altekruse SF, McGlynn KA, Dickie LA, Kleiner DE. Hepatocellular carcinoma confirmation, treatment, and survival in Surveillance, Epidemiology, and End Results registries, 1992-2008. Hepatology 2012; 55: 476-82.

20. Somboon K, Siramolpiwat S, Vilaichone RK. Epidemiology and survival of hepatocellular carcinoma in the central region of Thailand. Asian Pac J Cancer Prev. 2014; 15: 3567-70.

21. Jemal A, et al: Cancer statistics, 2003. CA Cancer J Clin 2003; 53: 5-26.

22. Razumilava N, Lazaridis KN, Gores GJ. Cholangiocarcinoma. In: Sanyal AJ (ed). Zakim and Boyer's Hepatology: A Textbook of Liver Disease, 7th ed. Philadelphia, PA : Elsevier, 2018; 693-707.

23. Chang DK, Jamieson NB, Johns AL, et al. Histomolecular phenotypes and outcome in adenocarcinoma of the ampulla of vater. J Clin Oncol 2013; 31: 1348-56. 